\title{
A New High-Frequency Voltage Injection Method for Sensorless Drive of Permanent-Magnet Synchronous Motors with Pole Saliency
}

\author{
Shinji ShinnakaＭember (Kanagawa University, shinnaka@kanagawa-u.ac.jp)
}

Keywords: speed-varying-ellipse high-frequency voltage, generalized integral-type PLL method, high-frequency current autocorrelated signal, synchronous motor, sensorless

This paper proposes a new sensorless vector control method for salient-pole permanent-magnet synchronous motors. In regard to rotor phase estimation, the sensorless vector control method is featured by a new high-frequency voltage injection method distinguished from the conventional ones by a unique ellipse shape of the spatially rotating, and by a new PLL method whose input is a high frequency current auto-correlated signal. The new vector control method established by two innovative technologies can have the high-performance and attractive features as follows.

1) It can allow $250 \%$ rated torque at standstill.

2) It can operate from zero to the rated speed under the rated motoring or regenerating load.

3) It accepts instant injection of the rated load even for zero-speed control.

4) It accommodates a load with huge moment of inertia.

5) Phase estimation is very robust against inverter dead time.

6) Computational load for estimating rotor phase is very small, would be the smallest among the methods with comparable performance.

This paper presents the new vector control method by focusing on two innovative technologies from its principles to design rules. Usefulness of the new vector control method is verified through extensive experiments.

Fig. 1 shows a structure of the proposed new sensorless vector control system. Phase and speed of the rotor are estimated in the "phase estimator," whose structure can be illustrated as in Fig. 2. As shown, it simply consists of two single-input/output band-pass filters, a single-input/output low-pass filter, a phase synchronizer, and a speed-variable- ellipse high-frequency voltage commander (SVEHFVC). The phase synchronizer is a kind of so-called PLL, but whose input is a high-frequency current correlated signal. SVEHFVC generates high-frequency voltage command of unique ellipse shape. The phase estimator is very simple, but its performance is excellent as demonstrated in the following.

Fig. 3 shows a example of torque responses at standstill to the $250 \%$ rating torque command, where wavelike data imply, from the top, q-current, u-phase current, actual rotor phase and its estimate. It is clearly observed that the phase is well estimated and $250 \%$ rated q-current (torque-producing current) is well controlled although the rotor starts to rotate at instant of torque command injection due to narrow speed bandwidth of the load machine controlled to be zerospeed.

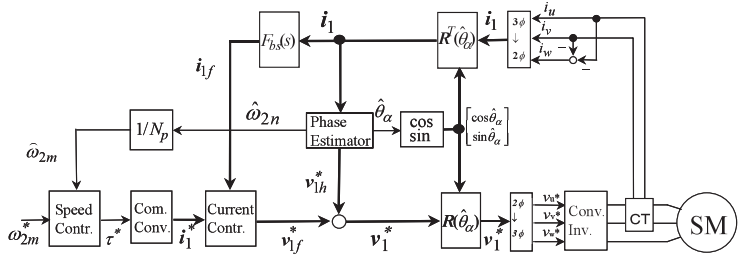

Fig. 1. A configuration of the proposed sensorless vector control system.

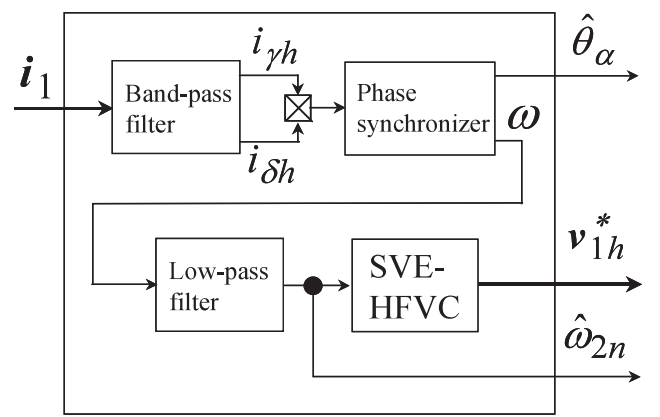

Fig. 2. A configuration of the phase estimator.

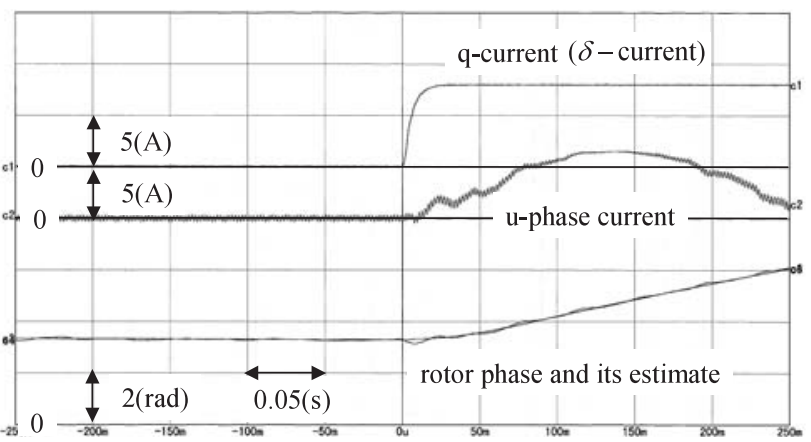

Fig. 3. Torque response producing $250 \%$ rating at ultra low speed including standstill. 


\title{
突極形永久磁石同期モータセンサレス駆動のための 速応楕円形高周波電圧印加法の提案
}

\author{
一高周波電流相関信号を入力とする一般化積分形PLL 法による位相推定一
}

\author{
正 員 新中 新二*
}

\section{A New High-Frequency Voltage Injection Method for Sensorless Drive of Permanent-Magnet Synchronous Motors with Pole Saliency}

Shinji Shinnaka*, Member

\begin{abstract}
This paper proposes a new sensorless vector control method for salient-pole permanent-magnet synchronous motors. In regard to rotor phase estimation, the sensorless vector control method is featured by a new high-frequency voltage injection method distinguished from the conventional ones by a unique ellipse shape of the spatially rotating, and by a new PLL method whose input is a high frequency current auto-correlated signal. The new vector control method established by two innovative technologies can have the following high-performance and attractive features: 1) it can allow $250 \%$ rated torque at standstill; 2) it can operate from zero to the rated speed under the rated motoring or regenerating load; 3) it accepts instant injection of the rated load even for zero-speed control; 4) it accommodates a load with huge moment of inertia; 5) phase estimation is very robust against inverter dead time; 6) computational load for estimating rotor phase is very small, would be the smallest among the methods with comparable performance. This paper presents the new vector control method by focusing on two innovative technologies from its principles to design rules. Usefulness of the new vector control method is verified through extensive experiments.
\end{abstract}

キーワード : 速応棈円形高周波電圧，一般化積分形 PLL 法，高周波電流相関信号，同期モータ，センサレス

Keywords: speed-varying-ellipse high-frequency voltage, generalized integral-type PLL method, high-frequency current autocorrelated signal, synchronous motor, sensorless

\section{1. はじめに}

永久磁石形同期モー夕 (Permanent-Magnet Synchronous Motor, PMSM）のためのセンサレスベクトル制御法におけ る重要課題の 1 つは, ゼロ速度を含む低速域での適切な回 転子位置推定に基づく，高卜ルク発生にある（以下，位置 と位相を同義で使用する)。本課題の現実的な解決方法とし て, PMSM の高周波電圧に対する突極（Salient Pole, SP) 特性を利用した一定振幅高周波電圧印加法が種々提案され てきた ${ }^{(1) \sim(7)(10)}$ 。一定振幅高周波電圧印加法は，回転子 $\mathrm{N}$ 極 位相を推定すべく, 一定振幅の高周波電圧をモー夕駆動用 電圧に重畳印加するものである。本法は, 印加高周波電圧 がモー夕駆動用電流制御の観点からは外乱になると言う短 所を有する反面，これによる位相推定值は概してモータパ

\footnotetext{
*神奈川大学工学部電子情報フロンティア学科

干 221-8686 横浜市神奈川区六角橋 3-27-1

Dept. of Electrical Engineering, Kanagawa University

3-27-1, Rokkakubashi, Kanagawaku, Yokohama 221-8686
}

ラメータに不感と言う優れた長所を有する(1) (7)(10)。

既報の一定振幅高周波電圧印加法は, 電圧印加を行う座 標系上での電圧形状から, 一定振幅回転形と一定振幅非回 転形とに二別することができる ${ }^{(1) \sim(7)(10)}$ 。前者は, 印加座標 系上からみた場合，一定振幅で空間的に回転する高周波電 圧を印加するものであり, 座標各軸上の電圧形状は正弦形状 である (1) (3)。後者は, 印加座標系上からみた場合, 一定振幅 の非回転電圧を印加するものであり，空間的回転はしない。 電圧形状は正弦形状, 矩形形状が採用されている ${ }^{(4) \sim(7)(10)}$ 。

一定振幅高周波電圧印加法は, 上述のように, 元来, ゼロ 速度を含む低速域での高トルク発生を期して開発されてき た。しかし, 最近では, 電気自動車, ハイブリッド自動車 などへの応用に見られるように，ゼロ速度での 200〜250\% 定格の高卜ルク発生を可能とする位相推定性能と, ゼロ速 度から少なくとも $100(\mathrm{rad} / \mathrm{s})$ 以上の広速領域での安定推定 を可能とする位相推定性能とを同時に備えた位相推定方法 の開発が期待されている (本章末尾の注 1 参照) ${ }^{(8) \sim(10)}$ 。 一定振幅回転形高周波電圧印加法において，一般産業用 
の突極形永久磁石同期モー夕 (SP-PMSM) に対して，ゼロ 速度で $250 \%$ 定格トルク発生とゼロ速度から定格速度に及 ぶ広速域安定推定との成功例報告は, 現状では, 新中の提 案による鏡相形べクトル制御法の 1 方法が在るに過ぎない ようである ${ }^{(1)}$ 。鏡相形べクトル制御法では，回転子 $\mathrm{N}$ 極位 相へのゼロ位相差での同期を目指した座標系（以下，準同 期座標系と呼ぶ）上で，空間的に回転する一定振幅の高周 波電圧を印加し，この応答たる高周波電流を同座標系上で 電流鏡相特性に基づき処理して得た $\mathrm{N}$ 極位相推定值を一般 化積分形 PLL 法の入力とし, 固定座標系上で評価した回転 子 $\mathrm{N}$ 極位相推定值を得ている ${ }^{(1)}$ 。

一定振幅非回転形高周波電圧印加法の中で, 特に正弦形 状の高周波電圧を印加する方法は，藍原によって 1994 年 に提案された ${ }^{(4) \sim(6)}$ 。藍原の一定振幅非回転高周波電圧印加 法は，準同期座標系の主軸上で正弦形状の一定振幅高周波 電圧を印加し，この応答である高周波電流を同座標系副軸 上から抽出し, 抽出した高周波電流を FFT 処理し, FFT 処 理信号を比例 $(\mathrm{P})$ 方式の位相制御器を備えた積分形 PLLの 入力とし, 固定座標系上で評価した回転子 $\mathrm{N}$ 極位相推定值 を得るものである。その基本性能は, ゼロ速度での定格卜 ルク発生と, $0 \sim 1(\mathrm{rad} / \mathrm{s})$ 程度の運転範囲における安定推定 のようである ${ }^{(4) \sim(6) 。 ~}$

藍原の高周波電圧印加法は，Jang らによって改良が試み られ, 高周波電流に対して SP 特性を示す表面磁石形 PMSM に適用されている(7)。試みの要点は, 準同期座標系副軸上 から抽出した高周波電流を, FFT 処理に代わって, 抽出高 周波電流と同位相の正弦信号を別途用意してこれに乗じた 上でローパスフィルタ処理し（この種の処理はフェテロダ イン処理といわれる $\left.{ }^{(2)(3)}\right)$, フィルタリング信号を，バング バング位相制御器を備えた積分形PLL の入力信号とするこ とにある。改良後の基本性能は，ゼロ速度での約 120\%定 格トルク発生と， 0 2( $\mathrm{rad} / \mathrm{s})$ 程度の運転範囲における安定 推定のようである(7)。

本論文は, SP-PMSM 駆動のための高周波電圧印加法と して, 一定振幅の従来方法と異なった，新原理に基づく新 方法（以下，速応楕円形高周波電圧印加法と呼ぶ）と, こ れを用いたベクトル制御法（以下，速応楕円形ベクトル制 御法と呼ぶ）とを新規提案するものである。提案の高周波 電圧印加法とべクトル制御法は，以下のような際立った特 徵と性能を有する。

1) 速応棈円形高周波電圧印加法は, 準同期座標系上の非 回転高周波磁束を活用した位相推定法である。

2)速応楕円形高周波電圧印加法は, 非回転高周波磁束を 発生すべく，準同期座標系上で，回転子速度に応じた 棈円形状の高周波電圧を印加する。

3) 速応楕円形高周波電圧印加法は, 簡単であり, 実現に 要する演算負荷は極めて軽い。

4) 速応楕円形高周波電圧印加法による位相推定值は, イ ンバータデッドタイムの影響を受けにくい。

5)速応楕円形ベクトル制御法は，ゼロ速度で $250 \%$ 定格
という高トルク発生を行うことができる。

6) 速応楕円形ベクトル制御法は, 力行あるいは回生の定 格負荷の下で, ゼロ速度から定格速度まで運転可能で ある。

7) 速応楕円形ベクトル制御法は, ゼロ速度制御状態で，イ ンパクト定格負荷に耐える。

8) 速応楕円形べクトル制御法は, 大慣性負荷を駆動できる。 本論文は, 以下のように構成されている。次の第 2 章で は, SP-PMSM の数学モデルを与える。第 3 章では, 非回 転高周波磁束発生のための印加高周波電圧の条件, 非回転 高周波磁束に起因する非回転高周波電流とこれを利用した 準同期座標系上での位相推定の原理を, 数学モデルに基づ く統一理論を構築の上, 新規提示する。また, 本原理に適 合する高周波電圧の 1 つとして, 速応楕円形高周波電圧が 存在することを示す。次の第 4 章では, 速応楕円形高周波 電圧の応答たる高周波電流 2 成分の相関值（以下，高周波 電流相関信号と呼ぶ）を入力とする一般化積分形 PLL 法を 新規提示する。また, 本 PLL 法が安定動作し固定座標系か らみた適切な位相推定值を生成するための, 設計パラメー 夕の設計指針と指針に基づくパラメータ設計法とを新規に 与える。第 5 章では, 提案の速応楕円形ベクトル制御法に 立脚した全制御系の構造を概説する。第 6 章で実機実験に よる多数の検証結果を示す。第 7 章で, 本論文を総括する。 (注 1) 本論文では, 発生トルクに関する定格あるいは定格 值は，産業界一般で利用されている意味で，すなわ ち連続運転可能な最大值の意味で使用している。電 気自動車では, 1 時間連続運転可能な最大値を定格 と呼ぶようである。

（注 2) 本論文では, 混乱の恐れのない限り, 記号 $s$ を微分 演算子 $d / d t$, またはラプラス演算子として，断りな く使用する。

（注 3) 本論文では，定理の証明等の終了が明瞭でない場合 には，これを明示すべく，適宜記号匹を付す。

\section{2. モータの数学モデル}

図 1 に示したように，任意の（角）速度 $\omega$ で回転する一 般 $\gamma-\delta$ 座標系を考える。主軸 ( $\gamma$ 軸) から副軸 $(\delta$ 軸) への 回転を正方向とする。また, SP-PMSM の回転子 $\mathrm{N}$ 極が $\gamma$ 軸に対し, ある瞬時に位相 $\theta_{\gamma}$ をなしているものとする。以 下に扱う SP-PMSM の物理量を表現した $2 \times 1$ ベクトル信号 は, 特に断らない限り, すべて本座標系上で定義されてい るものとする。SP-PMSMの数学モデルの導入に際し, 広 く採用されている以下の仮定を踏襲採用する ${ }^{(1) \sim(7)}$ 。

1)正弦着磁が施されている。

2)温度依存性は無視できる。

3)磁気回路の飽和特性は無視できる。

4)鉄損は無視できる。

5)漂游負荷損は無視できる。

上記仮定の下では, SP-PMSM の数学モデル（電気磁気 的関係）は， $2 \times 2$ 鏡行列 $\boldsymbol{Q}\left(\theta_{\gamma}\right)$ を用いた次式で表現される 


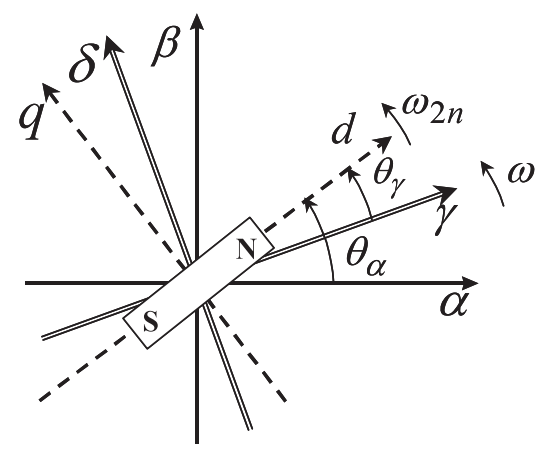

図 1 任意の速度 $\omega$ で回転する一般 $\gamma-\delta$ 座標系上 での回転子 $\mathrm{N}$ 極（突極）位相の関係

Fig. 1. Phase of rotor salient-pole (N pole) in $\gamma-\delta$ general reference frame rotating at arbitrary angular velocity $\omega$.

ことが知られている ${ }^{(11)}$ 。

[SP-PMSM の数学モデル (電気磁気的部分) $]^{(11)}$

$$
\begin{aligned}
& \boldsymbol{v}_{1}=R_{1} \boldsymbol{i}_{1}+[s \boldsymbol{I}+\omega \boldsymbol{J}] \boldsymbol{\phi}_{1} \\
& \phi_{1}=\phi_{i}+\phi_{m} \\
& \boldsymbol{\phi}_{i}=\left[L_{i} \boldsymbol{I}+L_{m} \boldsymbol{Q}\left(\theta_{\gamma}\right)\right] \boldsymbol{i}_{1} \\
& \boldsymbol{Q}\left(\theta_{\gamma}\right)=\left[\begin{array}{cc}
\cos 2 \theta_{\gamma} & \sin 2 \theta_{\gamma} \\
\sin 2 \theta_{\gamma} & -\cos 2 \theta_{\gamma}
\end{array}\right] \text {. } \\
& \boldsymbol{\phi}_{m}=\Phi \boldsymbol{u}\left(\theta_{\gamma}\right)=\Phi\left[\begin{array}{c}
\cos \theta_{\gamma} \\
\sin \theta_{\gamma}
\end{array}\right] ; \quad \Phi=\text { const } \\
& s \theta_{\gamma}=\omega_{2 n}-\omega .
\end{aligned}
$$

ここに，2×1ベクトル $v_{1}, i_{1}, \phi_{1}$ は，それぞれ固定子の電 圧, 電流, 磁束を意味している。 $2 \times 1$ ベクトル $\phi_{i}, \phi_{m}$ は固 定子磁束 $\phi_{1}$ を構成する成分を示しており， $\phi_{i}$ は固定子電 流 $\boldsymbol{i}_{1}$ によって発生した磁束を, $\boldsymbol{\phi}_{m}$ は回転子永久磁石に起 因する回転子磁束を意味している。I は $2 \times 2$ 単位行列であ $り, J$ は次式で定義された $2 \times 2$ 交代行列である。

$$
\boldsymbol{J}=\left[\begin{array}{cc}
0 & -1 \\
1 & 0
\end{array}\right]
$$

また, $\omega_{2 n}$ は回転子の電気 (角) 速度であり, $R_{1}$ は固定子巻 線の抵抗である。 $L_{i}, L_{m}$ は固定子の同相インダクタンス, 鏡相インダクタンスであり, $\mathrm{d}$ 軸, $\mathrm{q}$ 軸インダクタンスとは 次の関係を有する。

$$
\left[\begin{array}{l}
L_{d} \\
L_{q}
\end{array}\right]=\left[\begin{array}{cc}
1 & 1 \\
1 & -1
\end{array}\right]\left[\begin{array}{c}
L_{i} \\
L_{m}
\end{array}\right]
$$

(1)〜(8) 式においては，回転子 $\mathrm{N}$ 極での逆突極特性は, 同相インダクタンスの負性 $L_{m}<0$ で表現されている。

図 1 に明示しているように，SP-PMSM においては，N 極位相 $\theta_{\gamma}$ は逆突極の位相でもある。なお，㛜密には， $\mathrm{S}$ 極
でも逆突極が起こり，このため逆突極位相は $\mathrm{N}$ 極に対して $\pi(\mathrm{rad} / \mathrm{s})$ の曖昧性を持つ。しかし，以下では，NS 極の判定 は公知の方法で既に行なわれているものとして ${ }^{(9)(10)}, \mathrm{N}$ 極 位相と逆突極位相とは同義の回転子位相として使用する。

以下に説明する速応楕円形べクトル制御法では，一般 $\gamma-\delta$ 座標系上で電流制御を行い, 本座標系を同期 $\mathrm{dq}$ 座標系へゼ 口位相差で同期させることを目指す。すなわち, 以降では, $\gamma-\delta$ 座標系を準同期座標系とし，両座標系は同義とする。

\section{3. 非回転高周波磁束の生成とこれによる位相推定 の原理}

モー夕駆動用の電圧に高周波電圧を重畳することを考え る。この場合には, 次のように, 固定子の電圧, 電流, 磁 束は, 大きくは 2 成分の合成ベクトルとして表現すること ができる ${ }^{(1)}$ 。

$$
\left.\begin{array}{l}
\boldsymbol{v}_{1}=\boldsymbol{v}_{1 f}+\boldsymbol{v}_{1 h} \\
\boldsymbol{i}_{1}=\boldsymbol{i}_{1 f}+\boldsymbol{i}_{1 h} \\
\boldsymbol{\phi}_{1}=\boldsymbol{\phi}_{1 f}+\boldsymbol{\phi}_{1 h}
\end{array}\right\}
$$

ここに, 脚符 $f, h$ は, それぞれ駆動周波数 (FundamentalDriving-Frequency)，高周波（High-Frequency）の成分で あることを示している。なお，位相推定用に重畳した高周 波電圧の周波数は, 次の関係が成立する十分に高いものと する。

$$
\left\|R_{1} \boldsymbol{i}_{1 h}\right\| \ll\left\|[s \boldsymbol{I}+\omega \boldsymbol{J}] \boldsymbol{\phi}_{1 h}\right\| .
$$

(10) 式が成立する場合には，固定子の高周波成分である $\boldsymbol{v}_{1 h}$, $\boldsymbol{i}_{1 h}, \boldsymbol{\phi}_{1 h}$ に関しては, (1)〜(8) 式より, 以下の関係が成立す る(1)。

$$
\begin{aligned}
& \boldsymbol{v}_{1 h}=[s \boldsymbol{I}+\omega \boldsymbol{J}] \boldsymbol{\phi}_{1 h} \ldots \ldots \\
& \boldsymbol{\phi}_{1 h}=\left[L_{i} \boldsymbol{I}+L_{m} \boldsymbol{Q}\left(\theta_{\gamma}\right)\right] \boldsymbol{i}_{1 h} .
\end{aligned}
$$

(11)，(12) 式の固定子の高周波成分 $\boldsymbol{v}_{1 h}, \boldsymbol{i}_{1 h}, \boldsymbol{\phi}_{1 h}$ に関し ては，一般性に富む次の定理 1 が成立する。

[定理 1 (非回転高周波磁束定理)］

(a) 高周波電圧 $\boldsymbol{v}_{1 h}$ が，高周波スカラー信号 $x$ に対して (13) 式の関係をもつとき, 高周波磁束 $\phi_{1 h}$ は非回転信号と なる。

$$
\begin{aligned}
& \boldsymbol{v}_{1 h}=\left[\begin{array}{c}
s K_{\gamma}-\omega K_{\delta} \\
\omega K_{\gamma}+s K_{\delta}
\end{array}\right] x \\
& K_{\gamma}^{2}+K_{\delta}^{2}=1 \ldots \ldots \ldots .
\end{aligned}
$$

(b) (13) 式の高周波電圧 $\boldsymbol{v}_{1 h}$ に対する高周波電流 $\boldsymbol{i}_{1 h}$ は, 次の (14) 式となる。

$$
\boldsymbol{i}_{1 h}=\frac{1}{L_{d} L_{q}}\left[\begin{array}{c}
\left(L_{i}-L_{m} \cos 2 \theta_{\gamma}\right) K_{\gamma} \\
+\left(-L_{m} \sin 2 \theta_{\gamma}\right) K_{\delta} \\
\left(-L_{m} \sin 2 \theta_{\gamma}\right) K_{\gamma} \\
+\left(L_{i}+L_{m} \cos 2 \theta_{\gamma}\right) K_{\delta}
\end{array}\right] x
$$


〈証明〉

(a) 高周波磁束 $\phi_{1 h}$ の $\gamma$ 軸, $\delta$ 軸の各 2 成分を $\phi_{\gamma h}, \phi_{\delta h}$ と表現する。高周波磁束 $\phi_{1 h}$ が非回転信号であるためには, 高周波スカラー信号 $x$ に対して, 次の (15) 式の関係が成立 しなければならない。

$$
\boldsymbol{\phi}_{1 h}=\left[\begin{array}{c}
\phi_{\gamma h} \\
\phi_{\delta h}
\end{array}\right]=\left[\begin{array}{c}
K_{\gamma} \\
K_{\delta}
\end{array}\right] x
$$

(15) 式を(11) 式に用いると，(13a) 式が得られる。

(b) (15) 式を (12) 式に用いると, 次の関係が得られる。

$$
\begin{aligned}
\boldsymbol{i}_{1 h} & =\left[L_{i} \boldsymbol{I}+L_{m} \boldsymbol{Q}\left(\theta_{\gamma}\right)\right]^{-1} \boldsymbol{\phi}_{1 h} \\
& =\frac{1}{L_{i}^{2}-L_{m}^{2}}\left[L_{i} \boldsymbol{I}-L_{m} \boldsymbol{Q}\left(\theta_{\gamma}\right)\right]\left[\begin{array}{c}
K_{\gamma} \\
K_{\delta}
\end{array}\right] x
\end{aligned}
$$

(4)，(8) 式の関係を (16) 式に用いると，(14) 式が得られる。

定理 1 の (14) 式が明白に示しているように，このときの 高周波電流は非回転となる。ただし, 非回転高周波電流の 空間的方向は，高周波磁束のそれと必ずしも同一ではい。 両者間には回転子位相に応じたズレが存在する。換言する ならば, 高周波電流は回転子位相情報を有し，ひいては，高 周波電流の適切な処理を通じ, 回転子位相情報を抽出する ことが期待される。位相推定のセンサレスベクトル制御へ 利用を考える場合, 非回転高周波磁束の空間的方向の有力 候補の 1 つが $\gamma$ 軸方向である。これに関しては, 次の定理 2 が成立する。

[定理 2( $\gamma$ 形非回転高周波磁束定理)]

(a) 高周波電圧 $\boldsymbol{v}_{1 h}$ の $\gamma$ 軸, $\delta$ 軸の各 2 成分を $v_{\gamma h}, v_{\delta h}$ と 表現する。このとき, 高周波電圧に関し (17) 式の関係が成 立する場合には，

$$
\begin{aligned}
& \boldsymbol{v}_{1 h}=\left[\begin{array}{c}
v_{\gamma h} \\
v_{\delta h}
\end{array}\right] \\
& v_{\delta h}=\omega\left(\frac{v_{\gamma h}}{s}\right) .
\end{aligned}
$$

高周波磁束 $\phi_{1 h}$ は, (18) 式の $\gamma$ 軸上の非回転信号となる。

$$
\boldsymbol{\phi}_{1 h}=\left[\begin{array}{c}
\frac{v_{\gamma h}}{s} \\
0
\end{array}\right]
$$

(b) (17) 式の高周波電圧 $\boldsymbol{v}_{1 h}$ に対する高周波電流 $\boldsymbol{i}_{1 h}$ は, 次の (19) 式となる。

$$
\boldsymbol{i}_{1 h}=\frac{1}{L_{d} L_{q}}\left[\begin{array}{c}
L_{i}-L_{m} \cos 2 \theta_{\gamma} \\
-L_{m} \sin 2 \theta_{\gamma}
\end{array}\right]\left(\frac{v_{\gamma h}}{s}\right) \ldots \ldots \ldots \ldots
$$

\section{〈証明〉}

(a) (15) 式より明白なように, 高周波磁束 $\phi_{1 h}$ を $\gamma$ 軸上 の非回転信号とするには，次の条件が必要である。

$$
\left.\begin{array}{l}
K_{\gamma}=1 \\
K_{\delta}=0
\end{array}\right\}
$$

(20) 式を(13) 式に適用すると, 次式を得る。

$$
v_{1 h}=\left[\begin{array}{c}
v_{\gamma h} \\
v_{\delta h}
\end{array}\right]=\left[\begin{array}{c}
s \\
\omega
\end{array}\right] x
$$

(21) 式第 1 行より, このときの高周波スカラー信号 $x$ は次 の関係を満足しなければならない。

$$
x=\frac{v_{\gamma h}}{s} \cdots
$$

(22) 式を (21) 式第 2 行に用いると，(17b) 式が得られる。

(b) (20), (22) 式を，(14) 式に適用すると, 直ちに(19) 式 が得られる。

$\gamma$ 軸上に非回転高周波磁束 $\boldsymbol{\phi}_{1 h}$ を発生させるための高周 波電圧は，(17) 式の条件を満足すればよい。(17) 式は, 高 周波電圧の $\gamma$ 軸成分と $\delta$ 軸成分とは独立には選定できない ことを示している。 $\gamma$ 軸成分の実際的に取り得る形状とし ては, 正弦形状と矩形形状が考えられる。これに対応した $\delta$ 軸成分の形状は, 各々, 正弦形状と三角形状となる。何 れの形状の電圧も発生は容易であるが, 高周波電圧の応答 たる高周波電流の処理の平易さを考慮し, 本論文では, 正 弦形状の高周波電圧を採用することを考える。正弦形状の 高周波電圧に関しては, 次の定理 3 が成立する。

\section{[定理 3 (速応楕円電圧定理) ]}

(a) 高周波 $\omega_{h}$ の高周波電圧を, 速度 $\omega$ に応じた棈円軌跡 をもつ(23) 式とする場合には,

$$
v_{1 h}=V_{h}\left[\begin{array}{c}
\cos \omega_{h} t \\
\frac{\omega}{\omega_{h}} \sin \omega_{h} t
\end{array}\right] ; \quad \begin{array}{ll}
V_{h}=\text { const } \\
\omega_{h}=\text { const }
\end{array}
$$

これに対する高周波電流は(24) 式となる。

$$
\boldsymbol{i}_{1 h}=\frac{V_{h}}{\omega_{h} L_{d} L_{q}}\left[\begin{array}{c}
L_{i}-L_{m} \cos 2 \theta_{\gamma} \\
-L_{m} \sin 2 \theta_{\gamma}
\end{array}\right] \sin \omega_{h} t \ldots \ldots
$$

(b) (24) 式の高周波電流の 2 成分 $i_{\gamma h}, i_{\delta h}$ による高周波電 流相関信号 $i_{\gamma h} i_{\delta h}$ は, 回転子位相情報を内包する直流成分 $c_{i 1}$ と, $2 \omega_{h}$ 高周波成分 $c_{i 2}$ との線形和で構成される。すな わち,

$$
\begin{aligned}
& i_{\gamma h} i_{\delta h}=\left(2 \sin ^{2} \omega_{h} t\right) c_{i 1} \\
& =c_{i 1}+c_{i 2} \\
& \text { ただし， } \\
& c_{i 1}=\frac{-V_{h}^{2} L_{m}}{2 \omega_{h}^{2} L_{d}^{2} L_{q}^{2}}\left(L_{i}-L_{m} \cos 2 \theta_{\gamma}\right) \sin 2 \theta_{\gamma} \ldots \ldots \\
& c_{i 2}=-c_{i 1} \cos 2 \omega_{h} t .
\end{aligned}
$$

\section{〈証明〉}

(a) (23) 式第 1 要素の関係を定理 2 に適用すると, 直ち に(23), (24) 式が得られる。

(b) (24) 式を用いて, 高周波電流相関信号 $i_{\gamma h} i_{\delta h}$ を算定す ると, (25) 式第 1 式を得る。ここで, 次の (27) 式の関係に 注意し,

$$
2 \sin ^{2} \omega_{h} t=\left(1-\cos 2 \omega_{h} t\right)
$$


(25) 式第 1 式を直流成分と高周波成分とに分離すると，(25) 式第 2 式を得る。

(25) 式の高周波電流相関信号を形成する, 位相情報と持っ た直流成分 $c_{i 1}$ と高周波成分 $c_{i 2}$ とは， $2 \omega_{h}$ の周波数的開き をもっており，直流成分に対する高周波成分の排除は可能 である。

(26a) 式に示した直流成分は，位相 $\theta_{\gamma}$ が小さい場合には, 以下のように整理される。

$$
c_{i 1} \approx K_{\theta} \theta_{\gamma}
$$

ただし，

$$
K_{\theta}=\frac{-V_{h}^{2} L_{m}}{\omega_{h}^{2} L_{d}^{2} L_{q}}>0
$$

高周波数 $\omega_{h}$ が定数であり， $K_{\theta}$ が正の一定值であることを 考えると，(28)，(29) 式は，高周波電流相関信号の直流成 分 $c_{i 1}$ と準同期座標系 $\gamma$ 軸からみた位相 $\theta_{\gamma}$ とは単純な比例 関係にあることを意味している。本論文提案の速応楕円形 高周波電圧印加法による位相推定は本特性を利用するもの であり, これは, 以下のステップ1)〜3)の処理として整理 することができる。

1)(23) 式の速応楕円形高周波電圧を印加して，(24) 式の 非回転高周波電流を発生させる。

2)非回転高周波電流を用いて，(25) 式の高周波電流相関 信号を生成する。

3)(28)，(29) 式に示した高周波電流相関信号の特性を利 用して, 高周波電流相関信号より，直接的に，固定座 標系の基軸である $\alpha$ 軸からみた回転子位相 $\theta_{\alpha}$ を推定 する。

次に，ステップ 3)の処理を説明する。

(注 4) 上記の位相推定原理より明白なように，突極性がな い $L_{m}=0$ の状況下では, 提案法は位相を推定する ことはできない。反対に, 磁束飽和の下でも突極性 が存在すれば，提案法の適用は可能である（後揭の 図 14 参照)。

\section{4. 高周波電流相関信号を入力とする一般化積分形 PLL の安定化設計法}

\section{$\langle\mathbf{4} \cdot \mathbf{1}\rangle$ 一般化積分形 PLL 法と新課題 SP-PMSM の} センサレスベクトル制御には, 固定座標系の基軸である $\alpha$ 軸からみた回転子位相 $\theta_{\alpha}$ が必要である。本論文では, 高周 波電流相関信号 $i_{\gamma h} i_{\delta h}$ に, 新中によって体系化された一般 化積分形 PLL (Phase Locked Loop) 法 ${ }^{(12)}$ を適用すること により，回転子位相 $\theta_{\alpha}$ を推定することを考える。

一般化積分形 PLL 法は, 入力信号 $u_{P L L}$ に対して以下の ように構成されている(12)。

\section{[一般化積分形 PLL 法]}

$$
\begin{aligned}
& \omega=C_{P L L}(s) u_{P L L} \\
& \hat{\theta}_{\alpha}=\frac{1}{s} \omega
\end{aligned}
$$

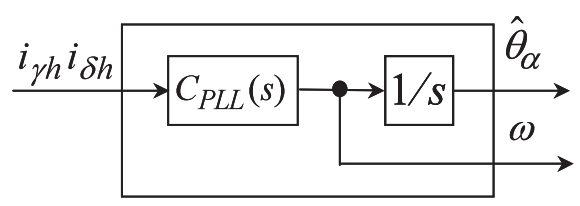

図 2 一般化積分形PLL 法の実現

Fig. 2. A realization of the generalized integral-type PLL method.

ただし，

$$
\begin{aligned}
C_{P L L}(s) & =\frac{C_{n}(s)}{C_{d}(s)} \\
& =\frac{c_{n m} s^{m}+c_{n m-1} s^{m-1}+\cdots+c_{n 0}}{s^{m}+c_{d m-1} s^{m-1}+\cdots+c_{d 0}} \cdots \cdots
\end{aligned}
$$

ここに, $c_{d i}, c_{n i}$ はそれぞれ位相制御器 $C_{P L L}(s)$ の特性を定 めるパラメータである。

一般化積分形 PLL 法は, 元来, 入力信号 $u_{P L L}$ として, 準 同期座標系 $\gamma$ 軸からみた位相 $\theta_{\gamma}$ の良好な推定值を想定し ている。位相 $\theta_{\gamma}$ の良好な推定值が得られ, 位相制御器が適 切に設計される場合には， $\hat{\theta}_{\alpha} \rightarrow \theta_{\alpha}$ （すなわち，位相ロッ ク）が達成されることが解明されている(12)。

準同期座標系 $\gamma$ 軸からみた位相 $\theta_{\gamma}$ の良好な推定值に代 わって, 本論文では, 総合的簡単性等を考慮し, (25), (26) 式に示した高周波電流相関信号 $i_{\gamma h} i_{\delta h}$ そのものを, 一切の 処理をすることなく, 位相制御器への入力信号 $u_{P L L}$ とする ことを提案する ( $44 \cdot 2\rangle$ 節末尾の注 5,6 参照 $)$ 。以降では, 未処理の高周波電流相関信号 $i_{\gamma h} i_{\delta h}$ そのものを入力信号と する位相制御器 $C_{P L L}(s)$ を, 高周波位相制御器と呼ぶ。高 周波位相制御器を用いた一般化積分形 PLL 法の構成を図 2 に示す。

高周波位相制御器の設計には，入力たる高周波電流相関 信号に含まれる $2 \omega_{h}$ 高周波成分によるPLL システムへの 影響に対して, 特別の注意が必要である。さもなくば, PLL システムの位相ロック機能はもとより, 安定な動作さえ達 成することができなくなる。次に, 高周波位相制御器の設 計について，設計指針とこれに基づく設計法とを説明する。

$\langle\mathbf{4} \cdot \mathbf{2}\rangle$ 高周波位相制御器の設計指針と設計法 本論 文では, PLL システムの安定性と位相ロック機能の確立と, 更には，入力信号に含まれる高周波成分の PLL システムの フィードバックループ機能を利用した自動排除とを可能と する高周波位相制御器の設計を考える。

高周波位相制御器をもつ PLL システムは，(25)，(26), (30) 式により，図 3(a) のようにモデル化することができる。 特に, (28) 式が成立する場合, 同システムは同図 (b) のよう にモデル化することができる。図 3 より明白なように，本 PLL システムは, (28) 式が成立する場合さえも, 高周波信 号 $\cos 2 \omega_{h} t$ に起因する強い非線形性を有する。このため, PLL システムに所期の位相ロック性能を発揮させるには, 高周波位相制御器は, 本非線形性を考慮して設計されなけ ればならならない。 


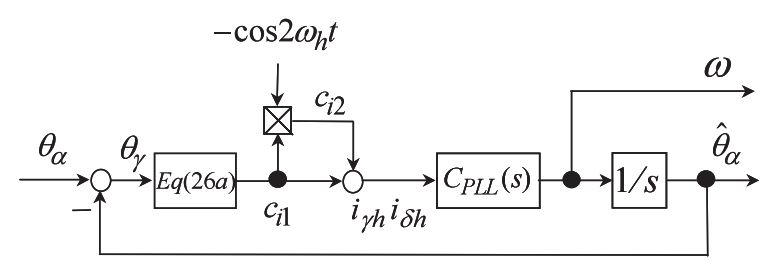

(a) model A

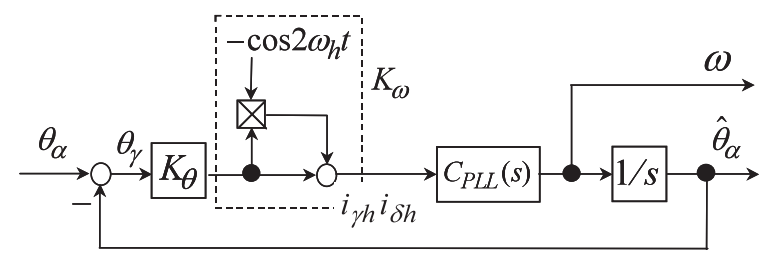

(b) model B

図 3 位相同期器による PLL システムのモデル

Fig. 3. A model for the PLL system by the phase synchronizer.

本論文では, 図 3(b) のモデル B を参考に, 高周波位相制 御器の設計指針として次のものを新規提案する。

\section{[高周波位相制御器の設計指針]}

1) 次の $(\mathrm{m}+1)$ 次 $H(s)$ が, 任意の $0<K_{\omega} \leq 2$ に対して, フルビッツ (Hurwitz) 多項式となる。

$$
H(s)=s C_{d}(s)+K_{\omega} K_{\theta} C_{n}(s) ; 0<K_{\omega} \leq 2 \ldots
$$

2) $C_{d}(s)$ が単独の形式で $s$ 因子をもつ。

指針 1) は, $2 \omega_{h}$ 高周波成分 $c_{i 2}$ の混入を, PLL システム内 の変動等価係数 $0<K_{\omega} \leq 2$ として等価的に扱い（図 3(b) 参照), 高周波成分の存在にもかかわらず, PLL システム を安定に動作させる高周波位相制御器の設計を可能とする ためのものである。指針 2) は, 一定速運転中における座標 速度 $\omega$ に高周波成分の出現を原理的に防止する高周波位相 制御器の設計を可能とするためのものである。

上の設計指針に基づく高周波位相制御器の具体的な設計 法としては，次の定理 4 が成立する。

\section{[定理 4 (高周波位相制御器定理) ]}

(a) $C_{d}(s)$ が単独形式で $s$ 因子をもつ高周波位相制御器と して，これを (33) 式のように設計する場合には，H(s)は， 任意の $0<K_{\omega} \leq 2$ に対して, フルビッッ多項式となる。

$$
\begin{aligned}
& C_{P L L}(s)=\frac{c_{n 1} s+c_{n 0}}{s} \\
& c_{n 0}>0, c_{n 1}>0 \ldots \ldots
\end{aligned}
$$

(b) $C_{d}(s)$ が単独形式で $s$ 因子をもつ高周波位相制御器と して，これを (34) 式のように設計する場合には， $H(s)$ は, 任意の $0<K_{\omega} \leq 2$ に対して, フルビッッ多項式となる。

$$
\begin{aligned}
& C_{P L L}(s)=\frac{c_{n 1} s+c_{n 0}}{s\left(s+c_{d 1}\right)} \\
& c_{n 0}>0, c_{n 1}>0, c_{d 1}> \\
& c_{d 1}>\frac{c_{n 0}}{c_{n 1}}
\end{aligned}
$$

〈証明〉

(a) $C_{d}(s)$ が単独形式で $s$ 因子をもつには, (33a) 式より, $c_{n 0} \neq 0$ の条件が必要である。この場合，(33a) 式に対する $H(s)$ は，(32) 式より，次式となる。

$$
H(s)=s^{2}+K_{\omega} K_{\theta}\left(c_{n 1} s+c_{n 0}\right) \cdot
$$

従って, $H(s)$ がフルビッツ多項式となる条件は, $0<K_{\omega} \leq 2$ の值に関係せず，(33b) 式となる。

(b) $C_{d}(s)$ が単独形式で $s$ 因子をもつには，(34a) 式より, $c_{n 0} \neq 0$ の条件が必要である。この場合，(34a) 式に対する $H(s)$ は，(32) 式より，次式となる。

$$
H(s)=s^{3}+c_{d 1} s^{2}+K_{\omega} K_{\theta}\left(c_{n 1} s+c_{n 0}\right) \cdots
$$

従って, $H(s)$ がフルビッツ多項式となる条件は, $0<K_{\omega} \leq 2$ の值に関係せず，(34b) 式となる。

高周波成分 $c_{i 2}$ の混入は, 等価係数において $K_{\omega}=0$ の瞬 時発生を含む。 $K_{\omega}=0$ の瞬時発生は, 図 3 より明らかなよ うに, 高周波位相制御器への入力信号ゼロを意味する。提 示の設計方針に従った定理 4 の高周波位相制御器は積分要 素をもつので, 入力信号ゼロの瞬時発生に対しては, 高周 波位相制御器の内部信号と出力信号は瞬時ゼロ発生の直前 值を維持する。すなわち, 高周波位相制御器は, 入力信号 ゼロの瞬時発生に対して, 最も好ましい応答を示し不安定 化することはない。

定理 4 の (33), (34) 式に提示した高周波位相制御器と同 設計法は, 高周波成分 $c_{i 2}$ の混入を等価的に表現した等価 係数の条件が出現しておらず, 高周波成分混入のない従来 の位相制御器と同設計法と, 形式的には同一である。しか し, 定理 4 は, その証明が明示しているように, 従来考慮 されなかったPLL システムへ混入した高周波成分の影響と PLL システム自体によるこの自動排除とを, 新規に考慮し た上で新たに構築されたものである。この相違と新規性に は注意されたい（下の注 5,6 参照）。なお，従来のすべて の位相制御器が, 高周波位相制御器として利用できるわけ ではない。所期の性能機能をもつ高周波位相制御器は, 定 理 4 に示したものを含め, 極めて限定される。

(注 5) 高周波電流相関信号に含まれる高周波成分をローパ スフィルタで前処理し, 処理信号を高周波位相制御 器の入力信号とすれば, より簡単な高周波位相制御 器の設計・構成が行えるように思われるかもしれな い。この場合には, ローパスフィルタ自体も, PLL システムのフィードバックループに取り込まれるこ とになる。このため, PLL システムの安定動作の確 保には, 本ローパスフィルタの動特性を考慮の上, 高 周波位相制御器を設計する必要が生ずる。すなわち, ローパスフィルタの導入は, 期待に反し, かえって 安定動作を保証する高周波位相制御器の設計を複雑 化する。フィードバックループの安定性の観点から は, 導入のローパスフィルタは, 高周波位相制御器 の一部として捕らえる必要がある（図 3(a) 参照)。 
表 1 供試モー夕（SST4-20P4AEA-L）の特性

Table 1. Characteristics of test motor (SST4-20P4AEAL).

\begin{tabular}{|l|l|l|l|}
\hline$R_{1}$ & $2.259(\Omega)$ & rated torque & $2.2(\mathrm{Nm})$ \\
\hline$L_{i}$ & $0.02662(\mathrm{H})$ & rated speed & $183.2(\mathrm{rad} / \mathrm{s})$ \\
\hline$L_{m}$ & $-0.00588(\mathrm{H})$ & rated current & $1.7(\mathrm{~A}, \mathrm{rms})$ \\
\hline$\Phi$ & $0.2165(\mathrm{~V} \mathrm{~s} / \mathrm{rad})$ & rated voltage & $163(\mathrm{~V}, \mathrm{rms})$ \\
\hline$N_{p}$ & 3 & moment of inertia & $0.0016\left(\mathrm{kgm}^{2}\right)$ \\
\hline $\begin{array}{l}\text { rated } \\
\text { power }\end{array}$ & $400(\mathrm{~W})$ & $\begin{array}{l}\text { effective resolution } \\
\text { of encoder }\end{array}$ & $4 \times 1024(\mathrm{p} / \mathrm{r})$ \\
\hline
\end{tabular}

(注 6) (34a) 式の高周波位相制御器は，位相補償付き I 制御 器, または 1 次ローパスフィルタ付き PI 制御器とし て，捕らえることもできる。すなわち，

$$
\begin{aligned}
C_{P L L}(s) & =\left(\frac{c_{n 1}}{s}\right) \cdot\left(\frac{s+c_{n 0} / c_{n 1}}{s+c_{d 1}}\right) \\
& =\left(\frac{c_{n 1}}{c_{d 1}}+\frac{c_{n 0}}{c_{d 1}} \frac{1}{s}\right) \cdot\left(\frac{c_{d 1}}{s+c_{d 1}}\right) \cdots \cdots
\end{aligned}
$$

これらのパラメータは，(34b) 式に与えたように，独 立に設計することはできない。

〈4·3〉 設計と応答の 1 例 定理 4 に基づく高周波位 相制御器 $C_{P L L}(s)$ の具体的な設計例と, これを用いた PLL システムの応答例を示す。

A. 設計例 供試モー夕（(株）安川電機製 SST420P4AEA-L）のパラメータは表 1 の通りとする。このと きの (23) 式の速応楕円形高周波電圧のパラメータは以下の 通りとする。

$$
\left.\begin{array}{l}
V_{h}=23 \\
\omega_{h}=2 \pi \cdot 400
\end{array}\right\}
$$

これより，(29) 式の $K_{\theta}$ として次を得る。

$$
K_{\theta}=\frac{-V_{h}^{2} L_{m}}{\omega_{h}^{2} L_{d}^{2} L_{q}}=0.0352251>0
$$

高周波位相制御器としては，(33) 式のものを考える。(33) 式に対応した (35) 式の $H(s)$ は $K_{\omega}=1$ で， $s=-75$ に2 重 根をもつフルビッッ多項式とすると，このための高周波位 相制御器パラメータは以下のように設計される。

$$
\left.\begin{array}{l}
c_{n o}=159687>0 \\
c_{n 1}=4258.33>0
\end{array}\right\}
$$

B. 応答例（40) 式の 2 パラメータを伴う (33) 式の高 周波位相制御器を利用して，図 3 の PLL システムモデル A 及びモデル B を構成し，位相ロック性能を確認した。この とき SP-PMSM は電気速度 $\omega_{2 n}=30(\mathrm{rad} / \mathrm{s})$ で一定速回転中 とし，また，PLL システムは，回転子位相 $\theta_{\alpha}=\pi / 4(\mathrm{rad} / \mathrm{s})$ のときに位相推定值の初期值を $\hat{\theta}_{\alpha}=0(\mathrm{rad} / \mathrm{s})$ とし, 位相 ロック動作を開始させた。両モデルによる実験結果を図 4 に示す。

図 4(a) は，位相ロックの様子を示したものである。同図

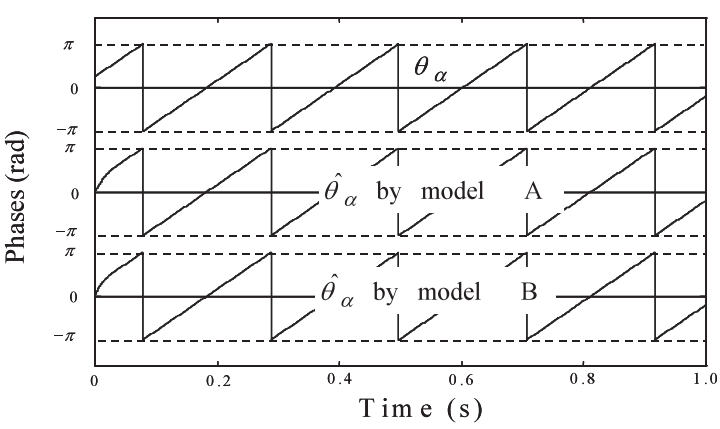

(a) True and estimated phases

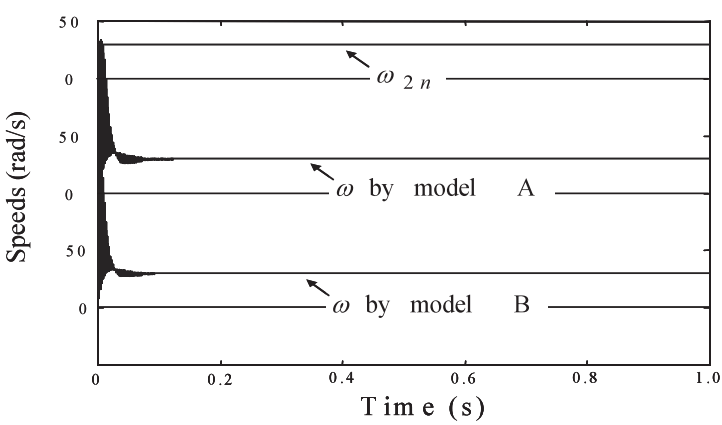

(b) True and estimated speeds.

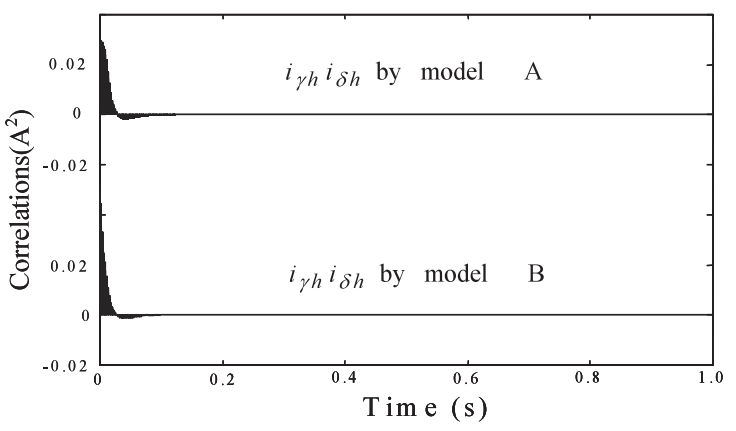

(c) Simulative generation of high-frequency current correlated signal.

図 4 PLL システムモデル A，B による応答例

Fig. 4. Response examples by PLL system models A and $\mathrm{B}$.

は，上から，回転子の位相真值，モデル A による位相推定 值，モデル B による位相推定值を各々示している。同図 (b) は，これに対応した速度を示したものである。すなわち，上 から，回転子の電気速度，モデル A による座標速度 $\omega$, モ デル B による座標速度 $\omega$ である。同図 (c) は, 図 (a), (b) に対応した高周波電流相関信号 $i_{\gamma h} i_{\delta h}$ である。すなわち, 上 から, モデル A による高周波電流相関信号, モデル B によ る高周波電流相関信号である。

図 4 より，定理 4 に基づき設計された高周波位相制御器 $C_{P L L}(s)$ を利用したPLL システムに関し，以下の 4 特性が 確認される。

1)PLL システムは，何れのモデルにおいても，安定に動 作している。

2)PLL システムは，何れのモデルにおいても，約 0.1(s) で位相ロックを完了している。

3)PLL システムは，何れのモデルにおいても，位相ロッ 
ク状態ではゼロ位相偏差, 及び高周波電流相関信号の 完全抑圧を達成している（(25), (26) 式参照)。また, このとき, 座標速度 $\omega$ から高周波成分が消滅し, 座標 速度 $\omega$ は電気速度 $\omega_{2 n}$ に対して速度偏差ゼロを達成し ている（(25), (26) 式参照)。

4) モデル B は，モデル A の良好な近似となっている。

上記 1) 4) 項の特性は, 高周波電流相関信号を入力とす る高周波位相制御器を用いた一般化積分形 PLL 法の妥当 性, 更には, 高周波位相制御器の設計指針及ぶ定理 4 に示し た同設計法の妥当性を裏づけるものでもある。なお，(34) 式の高周波位相制御器に関しても, 図 4 と同様な数值実験 を行い, 所期の位相推定性能を確認している。

\section{5. センサレスベクトル制御系}

〈5・1〉 全系の構成図 5 に, 本論文が提案する速応 楕円形高周波電圧印加法を利用したセンサレスベクトル制 御系（速応楕円形ベクトル制御系）の 1 構成例を示す。本 センサレスベクトル制御系と位置センサを利用した通常の ベクトル制御系の違いは, 準同期座標系 $(\gamma-\delta$ 座標系 $)$ 上の 電流情報から回転子の位相と（電気）速度とを推定する位 相推定器 (Phase Estimator と表示), ベクトル回転器 $\boldsymbol{R}^{T}(\cdot)$ 直後のバンドストップフィルタ $F_{b s}(\cdot)$ の有無にあり, 他は 同一である。以下，これらを順次説明する。

$\langle\mathbf{5} \cdot \mathbf{2}\rangle$ 位相推定器の構成 位相推定器は, 準同期座 標系上で定義された固定子電流の測定值 $\boldsymbol{i}_{1}$ を入力として受 け, ベクトル回転器に使用される固定 $\alpha-\beta$ 座標系上の回転 子位相推定值 (すなわち, 準同期座標系の位相) $\hat{\theta}_{\alpha}$, 回転子 電気速度の推定值 $\hat{\omega}_{2 n}$, 及び速応楕円形高周波電圧指令 $v_{1 h}^{*}$ の 3 信号を出力している。本器の構成の 1 例を図 6 に示し た。これはバンドパスフィルタ (Band-pass filter と表示), 位相同期器 (Phase Synchronizer と表示), ローパスフィル 夕 (Low-pass filter と表示), 及び速応楕円形高周波電圧指 令発生器 (Speed-Variable-Ellipse High-Frequency Voltage Commander, SVE-HFVC と表示) から構成されている。な お，図中の記号凶は乗算器を意味する。
A. バンドパスフィルタ 位相推定器は固定子電流を受 け取ると, 固定子電流の $\gamma \delta 2$ 成分に対して中心周波数 $\omega_{h}$ のバンドパスフィルタリング（通常は 2 次でよい）を施し, 2 個の高周波電流 $i_{\gamma h}, i_{\delta h}$ を抽出する。バンドパスフィルタ の出力信号は, (25) 式に従って高周波電流相関信号を得る ベく乗算され，位相同期器へ送られる。

B. 位相同期器 位相同期器は, 高周波位相制御器を用 いた一般化積分形 PLL 法に従い実現されており, その内部 構成は図 2 の通りである。位相同期器による位相ロック完 了後には, 準同期座標系の速度 $\omega$ が平均的には回転子電気 速度の推定值 $\hat{\omega}_{2 n}$ となる。設計指針 1), 2) に沿った定理 4 の高周波位相制御器によれば, 高周波電流相関信号が持ち うる高周波成分の座標速度 $\omega$ への出現を相当程度に抑圧す ることができる（実際的には, 種々の誤差のため, 高周波 出現は完全にはゼロにはならない)。

C. ローパスフィルタ 電気速度の推定に利用したロー パスフィルタ（通常は 1 次でよい）は, 残留高周波成分を 除去するためのものである。高周波位相制御器の設計如何 によるが, 一般に, 速度低下に応じて座標速度 $\omega$ に残留す る高周波成分は少なくなる傾向があるので, 運転がゼロ速 度近傍に限定される場合には, 本ローパスフィルタは必ず しも必要ない。

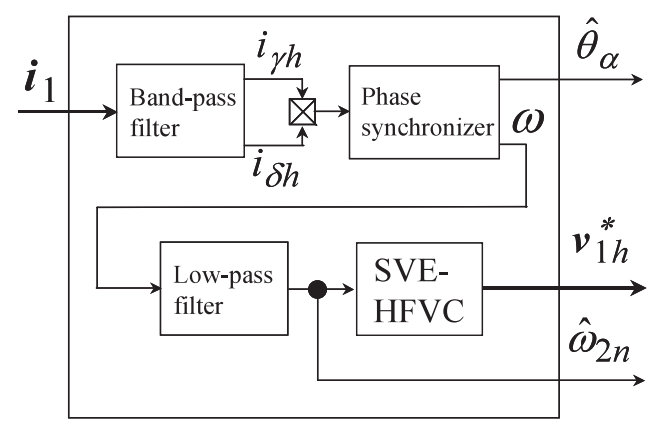

図 6 位相推定器の構造

Fig. 6. A configuration of the phase estimator.

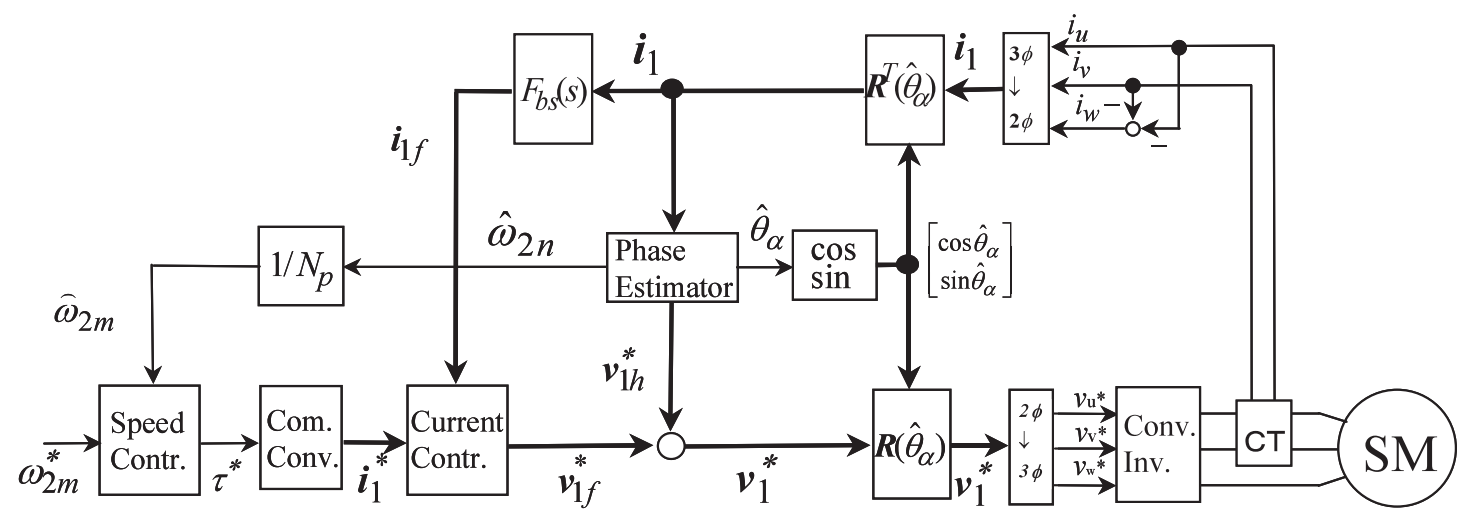

図 5 提案センサレスベクトル制御系の 1 構成例

Fig. 5. A configuration of the proposed sensorless vector control system. 


\section{D. 速応楕円形高周波電圧指令発生器 SVE-HFVC は,}

ローパスフィルタから電気速度推定值 $\hat{\omega}_{2 n}$ を受け取り，(23) 式に基づき，速応楕円形高周波電圧指令 $v_{1 h}^{*}$ を以下のよう に生成している。

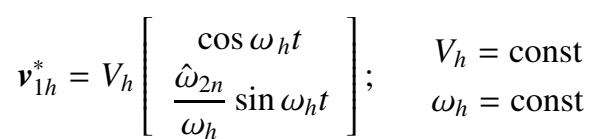

すなわち，実際的には，高周波成分を含む可能性のある準同 期座標系の速度 $\omega$ に代わって, これを排除した電気速度推 定值 $\hat{\omega}_{2 n}$ を利用して，速応楕円形高周波電圧指令を生成し ている。速応楕円形高周波電圧指令生成におけるパラメー 夕 $V_{h}, \omega_{h}$ は，速度推定值以外，すべて一定である。

以上の説明より明らかなように, 位相推定器の実行に要 する主要な演算は, 2 個の 2 次バンドパスフィルタ， 1 個の 1 次ローパスフィル夕, 及び 2 次または 3 次の位相同期器 によるものであり，総合演算負荷は大変軽い（図 6 参照）。 軽演算負荷は，提案の速応楕円形高周波電圧法の特筆す心゙ き特長の 1 つである。

$\langle\mathbf{5} \cdot \mathbf{3}\rangle$ その他の機器 電気速度推定值は, 極対数 $N_{p}$ で除されて機械速度推定值へ変換後, 速度制御器にも送ら れている (図 5 参照)。機械速度推定值は速度制御を遂行す るためのものであり, 当然のことながら, トルク制御には, 本機械速度推定值は必要ない。

図 5 に扮けるべクトル回転器 $\boldsymbol{R}^{T}(\cdot)$ 直後のバンドストッ プフィルタ $F_{b s}(\cdot)$ は，高周波電流によるフィードバック電 流制御系への回り込みを防止するためのものである。なお， 高周波 $\omega_{h}$ がフィードバック電流制御系の带域外に存在す る場合には，本フィル夕は必要ない。

\section{6. 実機実験}

〈6・1 実験システムの構成 提案の速応楕円形ベクト ル制御法の特性, 性能を確認すべく実験を行った。実験シス テムの様子を図 7 に示す。供試モー夕は，(株）安川電機製 400(W)SP-PMSM (SST4-20P4AEA-L) である (図 7 左端)。 その仕様概要は既に表 1 に示した通りである。本モー夕に は, 実効 4,096(p/r) のエンコーダが装着されているが，これ は回転子の位相・速度を計測するためのものであり, 制御に は利用されていない。負荷装置（図 7 右端）は，東洋電機製 造（株）製の 3.7 $(\mathrm{kW})$ 直流モー夕（DK2114 V-A02A-D01） であり, その慣性モーメントは $\mathrm{J}=0.085\left(\mathrm{kgm}^{2}\right)$, 定格速度 は 183(rad/s) である。トルクセンサ系 (図 7 中間) は（株) 共和電業製（TP-5KMCB，DPM-713B）である。

負荷装置は，供試モー夕に比し，約 53 倍の慣性モーメ ントを有している点には，注意されたい。実験システムの 用意の関係上，慣性モーメント的にはアンバランスの組合 せとなったが，大慣性負荷駆動の性能確認には好都合であ る。また，速応楕円形べクトル制御系は，七ンサとしては 2 個の $\mathrm{AC}$ 電流センサ（ゼロ周波数から動作可能なもの）, 1 個 DC 電圧センサのみを使用した，最少センサ構成で実 現されている点にも注意されたい。

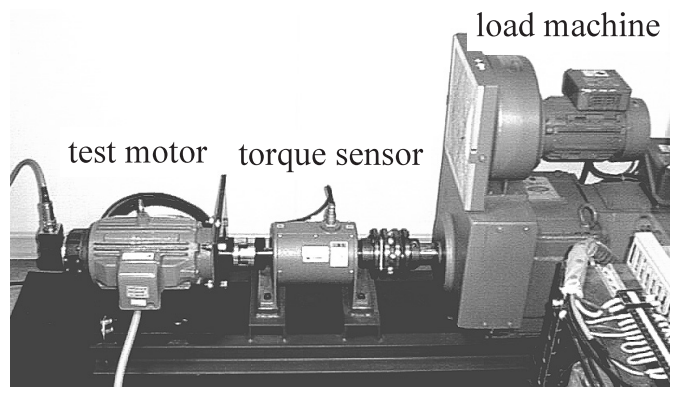

図 7 実験システム

Fig. 7. Test system setup.

$\langle\mathbf{6} \cdot \mathbf{2}\rangle$ 設計パラメータの概要 速応楕円形ベクトル 制御系に扔ける速応楕円形高周波電圧指令発生器の設計パ ラメータは (図 5, 図 6 参照), 〈4·3 節の (38) 式と同一と した。

位相推定器内のバンドパスフィルタは (図 5, 図 6参照), 2 次とし, 中心周波数 $\omega_{h}$, パスバンド $300(\mathrm{rad} / \mathrm{s})$ が得られ るように設計した。

位相推定器内の位相同期器を構成する高周波位相制御器 $C_{P L L}(s)$ としては (33) 式のものを考え（図 2, 眓 5, 図 6 参照), この設計パラメータはく4・3〉節の (40) 式と同一と した。

電流制御系は, 制御周期 $125(\mu s)$ と高周波電圧周波数 $\omega_{h}=2 \pi \cdot 400$ を考慮の上, 低めの带域 $1,800(\mathrm{rad} / \mathrm{s})$ が得 られるよう設計した。これに応じ，バンドストップフィル 夕 $F_{b s}(\cdot)$ は撤去した。トルク指令 $\tau^{*}$ の電流指令 $\boldsymbol{i}_{1 f}^{*}$ の変換 は, 回転子位相推定值の検証が行いやすいように, 次式に よった。

$$
i_{1 f}^{*}=\left[\begin{array}{c}
0 \\
\frac{1}{N_{p} \Phi} \tau^{*}
\end{array}\right] \ldots
$$

速度制御系は，供試モー夕の約 53 倍にも及ぶ負荷装置の 巨大な慣性モーメントを考慮し, 線形速度応答が確保され る概対上限帯域である帯域 $2(\mathrm{rad} / \mathrm{s})$ が得られるように設計 した。

図 5 に示した速応楕円形ベクトル制御系において，3/2 相変換器から $2 / 3$ 相変換器に至るすべての機能は, 単一の DSP（TMS320C32-50 MHz）で実現した。

\section{$\langle 6 \cdot 3\rangle$ 実験結果}

A. 速度制御（極低速時の定常応答）図 5 の構成にお いて，センサレスベクトル制御の重要な性能である，極低 速領域での速度制御性能を検証した。以下，波形デー夕を 用い検証結果を示す。

力行定格負荷の下で，定格速度比で約 $1 / 350$ に相当する 約 $0.5(\mathrm{rad} / \mathrm{s})$ の極低速度指令を与えた場合の応答を図 8 に 示す。図 8 上図の波形は, 上から, $\mathrm{U}$ 相電流, 回転子機械速 度 (エンコーダ検出値), 回転子位相の真値と推定值を意味 している。時間軸は 1 (s/div) である。U 相電流からは，駆 動用電流に重畳された高周波電流が明瞭に確認される。工 

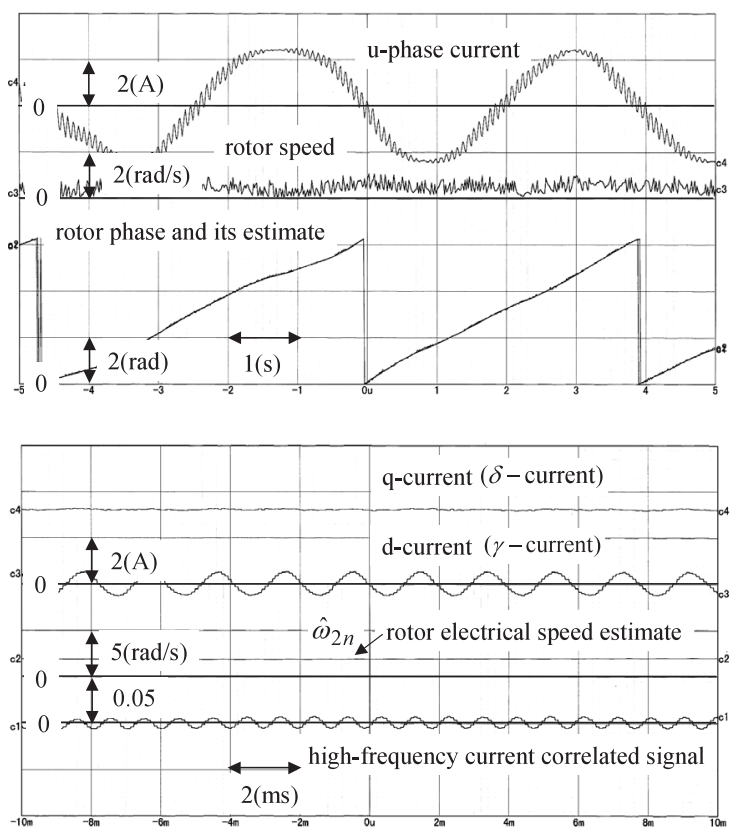

図 8 約 $0.5(\mathrm{rad} / \mathrm{s})$ 指令に対する力行定格負荷下 での応答

Fig. 8. Speed response to command of about $0.5(\mathrm{rad} / \mathrm{s})$ under the rated motoring load.

ンコーダにより測定した速度がスパイク状の突出を示して いるが，これは極低速運転に打けるエンコーダパルスの離 散的入力に起因している。回転子位相がほぼ直線的に変位 していることより明白なように，回転子は概ね一定速度す なわち約 $0.5(\mathrm{rad} / \mathrm{s})$ で回転を持続している。回転子位相の 真值と推定值との差 $\hat{\theta}_{\alpha}-\theta_{\alpha}$ は, 視認が困難なほど小さく, 平均約 $0.01(\mathrm{rad})$ であった。驚くべきことに，位相推定值 は，インバータのデッドタイム $(2.6(\mu \mathrm{s}))$ の影響を強く受 ける三相電流のゼロクロス点に打いても，一切の乱れを生 じていない (デッドタイム補正は未実施)。これは，鏡相形 ベクトル制御における位相推定值と異なる，特筆すべき特 長である(1)。

図 8 の下図は，上図と同一条件下での（すなわち，PLLに よる位相ロック完了後の）各種制御信号の様子である。波 形の意味は, 上から, $\mathrm{q}$ 軸電流 $(\delta$ 軸電流 $), \mathrm{d}$ 軸電流 $(\gamma$ 軸 電流), 回転子電気速度推定值, 高周波電流相関信号 $i_{\gamma h} i_{\delta h}$ である。ただし，時間軸は $2(\mathrm{~ms} / \mathrm{div})$ である。高周波電流 成分は, $\mathrm{q}$ 軸電流 ( $\delta$ 軸電流) には重盢せず， $\mathrm{d}$ 軸電流 $(\gamma$ 軸電流）にのみ重畳している点には，注意されたい。高周 波電流相関信号は微少ながら残存している。

回生定格負荷の下で，定格速度比で約 $1 / 350$ に相当する 約 $0.5(\mathrm{rad} / \mathrm{s})$ の極低速度指令を与えた場合の応答を図 9 に 示す。図 9 の波形の意味は, 図 8 と同一である。U 相電流 位相と回転子位相との位相逆転を除けば，力行の場合と同 様に，良好な制御が行われていることがわかる。なお，こ の場合も, 回転子位相の真値と推定值との差 $\hat{\theta}_{\alpha}-\theta_{\alpha}$ は視 認が困難なほど小さく，平均約 $-0.015(\mathrm{rad})$ であった。
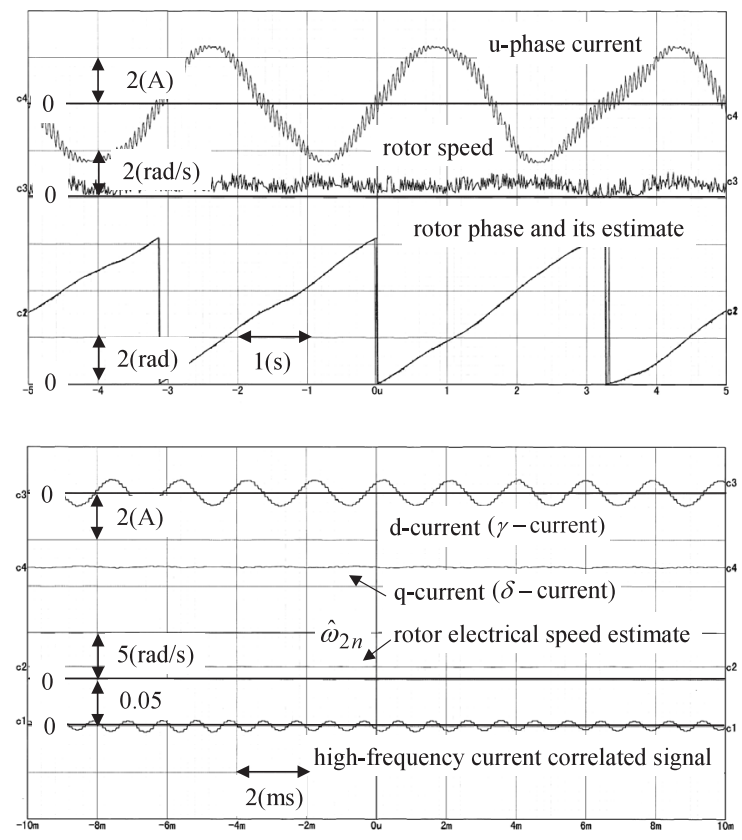

図 9 約 $0.5(\mathrm{rad} / \mathrm{s})$ 指令に対する回生定格負荷下 での応答

Fig. 9. Speed response to command of about $0.5(\mathrm{rad} / \mathrm{s})$ under the rated regenerating load.

なお，図 8, 図 9 においては，位相の摇らぎ，及びこれに 対応した約 $0.05(\mathrm{rad} / \mathrm{s})$ の速度の摇らぎが視認されるが，こ れは負荷装置のコギングトルクの影響と思われる。負荷装 置には微少なコギングトルクも, 軸出力約 $1 / 10$ の供試モー 夕には，大きな外乱トルク変動となる。

B. 速度制御（定格速時の定常応答）速応楕円形べク トル制御における高周波電圧は，(41) 式の電圧指令が示す ように，楕円長軸は回転子速度に関係なく一定であり，楕 円短軸のみが回転子速度に比例して変化する。回転子速度 に比例した楕円短軸の変化こそが, 一定振幅非回転形高周 波電圧印加法に対する速応棈円形高周波電圧印加法の決定 的な違いである。高周波電圧における短軸変化の効果を確 認すべく, 定格速度 $180(\mathrm{rad} / \mathrm{s})$ での応答を確認した。本定 格速度では, 速応楕円形高周波電圧の短軸/長軸の比は, 次 の大きな值を取る。

$$
\frac{\hat{\omega}_{2 n}}{\omega_{h}}=\frac{3 \cdot 180}{2 \pi \cdot 400} \approx 0.21
$$

力行定格負荷の下で，定格速度指令を与えた場合の応答 を図 10 に示す。図中の波形の意味は, 図 8 と同様である。

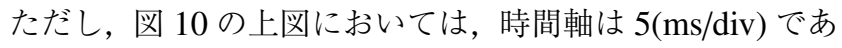
る。本応答においては, 回転子電気速度が高周波電圧の周 波数の $1 / 5$ に達しているため, U 相電流に重畳している高 周波電流の様子は必ずしも明瞭ではない。図 10 の下図で は, $\mathrm{q}$ 軸電流 $(\delta$ 軸電流 $), \mathrm{d}$ 軸電流 $(\gamma$ 軸電流 $)$, 高周波電 流相関信号 $i_{\gamma h} i_{\delta h}$ に若干の脈動が観察されるが, 全体的に は回転子位相が適切に推定され，良好な制御が維持されて いることが分かる。 

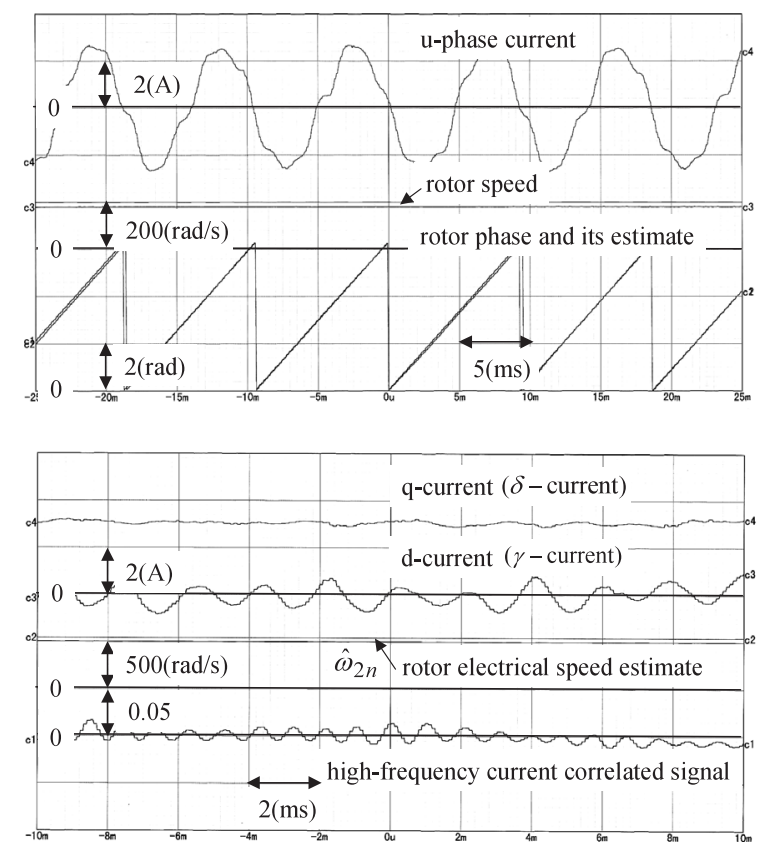

図 10 定格速度指令に対する力行定格負荷下 での応答

Fig. 10. Speed response to the rated speed command under the rated motoring load.

回生定格負荷の下で，定格速度指令を与えた場合の応答 を図 11 に示す。図中の波形の意味は，前揭図と同様であ る。なお，図 11 の上図においては，時間軸は $5(\mathrm{~ms} / \mathrm{div})$ で ある。U 相電流位相と回転子位相との逆転を除けば，力行 の場合と同様に，良好な制御が行われていることがわかる。

図 10, 図 11 より, 速応楕円形高周波電圧印加法における 回転子速度に応じた棈円短軸の変化の有効性が確認される。

C. ゼロ速度でのインパクト負荷特性ゼロ速度で安定 に制御がなされているか否かの最良の確認方法の 1 つは, 定格負荷の瞬時印加及び除去に対する安定制御の可否にあ る。図 12 は，この観点から，ゼ口速度指令の速度制御状態 で定格負荷を瞬時に印加し，負荷外乱抑圧に関する過渡応 答を調べたものである。図中の信号は，上部から，q 軸電 流 $(\delta$ 軸電流 $)$, 速度指令，同応答值，U 相電流を示してい る。時間軸は, 2(s/div)である。図より, 瞬時負荷に対して も安定したゼロ速度制御を維持し，かつこの影響を排除し ていることが確認される。

図 13 は，ゼロ速度制御の上，予め印加された定格負荷を 瞬時除去したときの応答である。波形の意味は前図と同様 である。安定な速度制御が確認される。定常状態に至って も，約 $1(\mathrm{~A})$ の $\mathrm{q}$ 軸電流（ $\delta$ 軸電流）が残っているが，これ は, 速度制御器として PI 制御器を利用し, 更には静止摩擦 が存在することに起因しており，正常な応答である。

なお，図 12 , 図 13 の両図において，ゼ口速度への回復 が遅いが，これは供試モー夕の約 53 倍にも及ぶ負荷装置 慣性モーメントを考慮し，速度制御带域を $2(\mathrm{rad} / \mathrm{s})$ に設計 したことに起因している。定格負荷の瞬時印加と瞬時除去
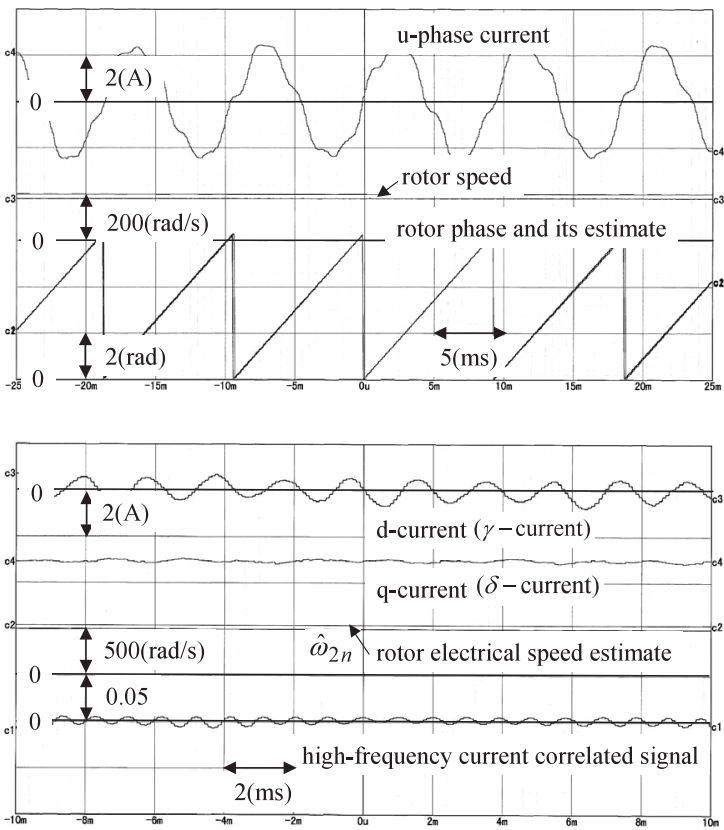

図 11 定格速度指令に対する回生定格負荷下 での応答

Fig. 11. Speed response to the rated speed command under the rated regenerating load.

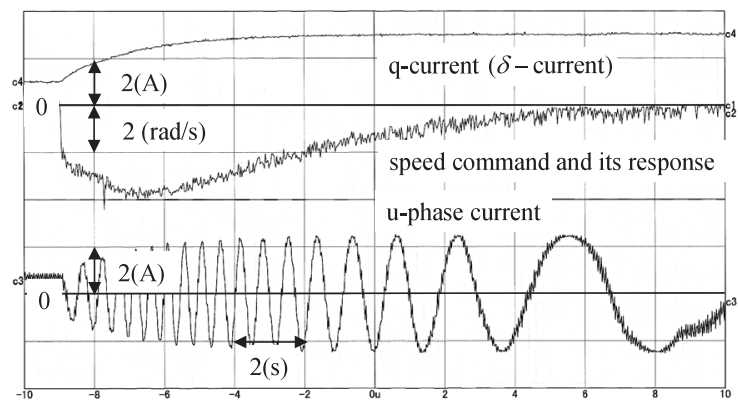

図 12 ゼロ速度での定格負荷による瞬時印加特性 （負荷慣性モーメント比：1/53）

Fig. 12. Response to instant injection of rated load at zero speed. (inertia ratio of test motor to load machine $: 1 / 53)$

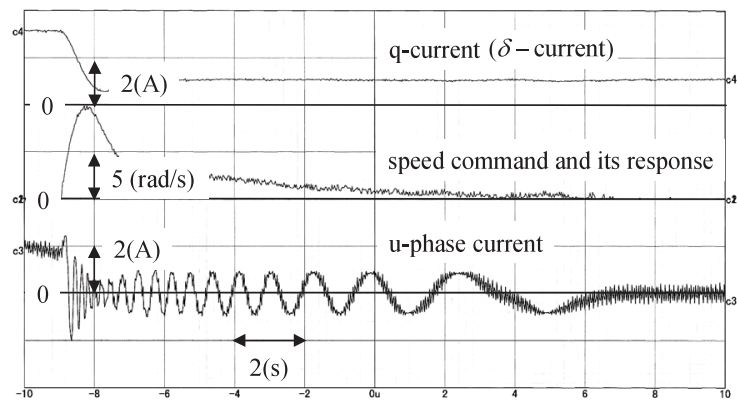

図 13 ゼロ速度での定格負荷による瞬時除去特性 （負荷慣性モーメント比：1/53）

Fig. 13. Response to instant elimination of rated load at zero speed. (inertia ratio of test motor to load machine $: 1 / 53)$ 


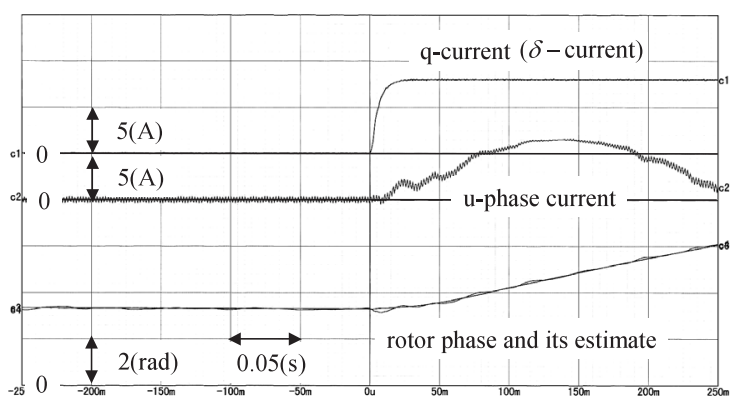

図 14 ゼロ速度近傍での定格 $250 \%$ トルク発生 応答例

Fig. 14. Torque response producing $250 \%$ rating at ultra low speed including standstill.

における応答の非対称性は，極低速運転における摩擦の非 線形特性によるものであり，応答は正常である。

D. ゼロ速度での高トルク応答センサレスベクトル制 御で最も困難とされているのは, ゼロ速度での高卜ルク発 生である。これまでの報告によれば，ゼロ速度を含む低速 域では $150 \%$ 定格以上のトルク発生は, $250 \%$ 定格卜ルク発 生に成功した鏡相形ベクトル制御が存在するものの, 大変

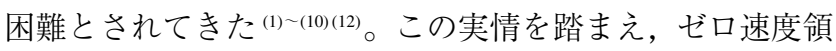
域での高トルク発生試験を行った。

図 5 の速応楕円形べクトル制御系において, 速度制御器 を撤去し, ベクトル制御系にトルク指令を直接印加できるよ うにシステム変更後，トルク制御の試験を実施した。図 14 は，負荷装置により供試モー夕の速度をゼロ速度状態に保 ち, 速応楕円形べクトル制御系に $250 \%$ 定格トルク発生の 指令を与えた場合の応答である。図中の信号は，上から，q 軸電流 $(\delta$ 軸電流)，U 相電流，回転子の位相真値，同推定 值を示している。時間軸は $0.05(\mathrm{~s} / \mathrm{div})$ である。電流軸は, 前掲の図 8〜図 13 と異なり，5(A/div) に変更されているの で, 注意されたい。約 10 倍の軸出力をもつ負荷装置の速度 制御系帯域が低いために，トルク指令印加直後に若干の位 相変動が見られるが，良好な位相推定と $\mathrm{q}$ 軸電流（ $\delta$ 軸電 流）より，所期のトルク発生が行われていることがわかる。

\section{7. おわりに}

以上，SP-PMSM のための高性能センサレスベクトル制 御法の 1 つとして, 新規な速応楕円形高周波電圧印加法と, これに基づく新規な速応楕円形べクトル制御法を提案した。

速応楕円形高周波電圧印加法に基づく回転子位相推定に 関しては, 非回転高周波磁束発生のための印加高周波電圧 の条件と, これ対応した非回転高周波電流による位相推定 の方法とを, 一般性に富む形で, 更には明快な解析的形で 提示した。また，位相推定の簡易実現に不可欠な，高周波 電流相関信号を入力とする一般化積分形 PLL 法を新規提 示し,この安定動作のための設計指針と設計法を新規に与 えた。

速応楕円形べクトル制御法に関しては，これが以下のよ
うな特長・有用性を有することを，実験を通じ検証した。

1) 速応楕円形高周波電圧印加法は, 簡単であり, 実現に 要する演算負荷は極めて軽い。

2) 速応棈円形高周波電圧印加法による位相推定值は, イ ンバータデッドタイムの影響を受けにくい。

3) 提案ベクトル制御法は, ゼロ速度で $250 \%$ 定格という 高トルク発生を行うことができる。

4) 速応楕円形べクトル制御法は, 力行あるいは回生の定 格負荷の下で, ゼロ速度から定格速度まで運転可能で ある。

5) 速応楕円形ベクトル制御法は, ゼロ速度制御状態で, イ ンパクト定格負荷に耐える。

6) 速応楕円形べクトル制御法は, 大慣性負荷を駆動できる。 検証実験に利用したSP-PMSM は駆動用電流に対しても $\mathrm{SP}$ 特性をもつ埋込磁石形 PMSM である。しかしながら, 表面磁石形PMSM であっても高周波電流に対して SP 特性 を示すならば(7), 提示の解析は有効であり, 提案法の利用 は可能である。以上の特長，性能はセンサレスベクトル制 御法としては極めて優れたものであり, 提案法の今後の活 用が期待される。

(平成 18 年 1 月 10 日受付)

\section{文献}

(1) S. Shinnaka: "A Mirror-Phase Based Sensorless Control of Salient-Pole PMSM", Trans. of SICE, Vol.40, No.5, pp.536-545 (2004-5) (in Japanese) 新中新二 :「突極形永久磁石同期モータのセンサレス駆動のための 鏡相形ベクトル制御」, 計測自動制御学会論文集, 40, 5, pp.536-545 (2004-5)

(2) M.J. Corley and R.D. Lorenz: "Rotor Position and Velocity Estimation for a Salient-Pole Permanent-Magnet Synchronous Machine at Standstill and High Speed", IEEE Trans. Industry Application, Vol.34, No.4. pp.784-789 (1998-8)

(3) L. Wang and R.D. Lorenz: "Rotor Position Estimation for PermanentMagnet Synchronous Motor Using Saliency-Tracking Self-Sensing Method", Conference Record of the 2000 IEEE Industrial Application Conference (IAS 2000), pp.445-450 (2000-10)

（4）藍原隆司：「電動機の磁極位置検出装置」, 日本国特許第 3312472 号 (1994-3-1)

（5）藍原隆司・鳥羽章夫・柳瀬孝雄：「センサレス方式による突極形同期 モータのゼロ速トルク制御」, 平 8 年電学産業応用部門大会講演論文 集, 3, pp.1-2 (1996-8)

(6) T. Aihara, A. Toba, T. Yanase, A. Mashimo, and K. Endo: "Sensorless Torque Control of Salient-Pole Synchronous Motor at Zero-Speed Operation", IEEE Trans. on Power Electronics, Vol.14, No.1, pp.202-208 (19991)

( 7 ) J.H. Jang, S.K. Sul, J.I. Ha, K. Ide, and M. Sawamura: "Sensorless Drive of Surface-Mounted Permanent-Magnet Motor by High-Frequency Signal Injection Based on Magnet Saliency", IEEE Trans. on Industry Applications, Vol.39, No.4, pp.1031-1039 (2003-7/8)

(8) S. Shinnaka and S. Takeuchi: "Development of a New Sensorless-VectorControlled and Transmissionless Electric Vehicle Using a PermanentMagnet Synchronous Motor", IEEJ Trans. IA, Vol.125, No.12. pp.11291138 (2005-12) (in Japanese)

新中新二・竹内 茂:「永久磁石同期モー夕を利用したセンサレス ベクトル制御駆動・トランスミッションレス電気自動車の開発」, 電 学論 D, 125, 12, pp.1129-1138 (2005-12)

(9) N. Patel, T. O'Meara, J. Nagashima, and R. Lorenz: "Encoderless IPM traction drive for EV/HEV", CD-Conference Record of the 2001 IEEE Industry Application Conference (IAS 2001) (2001-10)

(10) R. Masaki, S. Kanako, M. Hombu, T. Sawada, and S. Yoshihara: "Development of a Position Sensorless Control System on an Electric Vehicle Driven by a Permanent Magnet Synchronous Motor", Proc. of Power Conversion 
Conference-Osaka (PCC-Osaka 2002), pp.571-576 (2002-4)

(11) 新中新二：「同期モータの統一的ベクトル解析」, 平成 9 年電気学会 産業応用部門大会論文集, 2, pp.211-216 (1997-8)

(12) S. Shinnaka: "New Sensorless Vector Control Methods Based on New Minimum-Order Flux Sate-Observer in the D-Module for Permanent Magnet Synchronous Motors", IEEJ Trans. IA, Vol.123, No.12, pp.1445-1460 (2003-12) (in Japanese)

新中新二：「永久磁石同期モータの最小次元 $\mathrm{D}$ 因子状態オブザーバ

とこれを用いたセンサレスベクトル制御法の提案」, 電学論 D, 123,

12, pp.1445-1460 (2003-12)

新 中 新 二 (正員) 1973 年防衛大学校卒業。同年陸上自衛

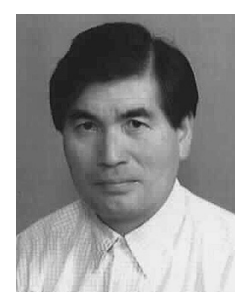
隊中央野外通信群入隊。1977 年 University of California, Irvine 大学院修士課程修了。1979 年同博 士課程修了。防衛庁技術研究本部第 1 研究所, 防 衛大学校電気工学教室等での奉職を終えて, 1986 年陸上自衛隊を除隊。同年キヤノン（株）勤務。 1991 年ベンチャー研究所創設。1996 年神奈川大 学電気工学科勤務 (教授, 現電子情報フロンティ ア学科)。2002 年同学市民 EV センター創設 (代表)。これまでの間, 通信，情報，制御，パワーエレクトロニクス分野の教育，研究，開発 及びこれらの管理等に従事。近年はサーボモータ駆動制御技術の体 系化に専念し，2001 年に誘導モータを用いたセンサレスベクトル制 御駆動・トランスミッションレス電気自動車（ST-EV）の世界初開発 に成功。本功績により 2002 年計測自動制御学会より技術賞を受賞。 2003 年 IEEE IAS-Transactions 論文賞受賞。2004 年永久磁石同期モ一 夕を用いた ST-EV の世界初開発に成功。同期モータセンサレス駆動制 御における周波数ハイブリッド基本概念（日本国特許第 3612636 号, 1996.9.18），ミール法基本概念（日本国特許第 3735836 号，2000.1.2, 第 3814826 号，2004.12.10），最小次元磁束状態オブザーバ基本概念 （日本国特許第 3653670 号，2002.8.31），鏡相推定基本概念（日本国特 許第 3328636 号，2000.3.17）等を含む多くの基本技術の第 1 提唱者。 電子情報通信学会, 計測自動制御学会, IEEE，欧州 EPE，自動車技術 会などの会員。Doctor of Philosophy 及び工学博士。 